\title{
The Urgency of the Legal Protection for Women to Protect Victims of Sexual Violence Due to Gender Inequality
}

\author{
Kadek Desy Pramita \\ \{desy.pramita@undiksha.ac.id\} \\ Universitas Pendidikan Ganesha, Indonesia
}

\begin{abstract}
This research aims to indentify and understand the scope of the current regulations governing sexual violence. As well as what regulations are needed so that women get protection from cases of sexual violence that often occur due to gender inequality. This research is a research that uses normative research methods using a qualitative descriptive approach, a conceptual approach and a statutory approach. Then by using primary, secondary and tertiary legal materials to get conclusions that are relevant to the problems at hand. The results showed that the Criminal Code, which is currently one of the references in handling cases of sexual violence, has not been able to cover all problems related to sexual violence. Therefore, additional regulations are needed as legal protection such as the Bill Draft on the Elimination of Sexual Violence which covers sexual violence in a more complex and comprehensive manner regarding sexual violence in Indonesia.
\end{abstract}

Keywords: gender inequality; sexual violence; women; legal protection

\section{Introduction}

Women are often seen as weak human beings and are not equal to men. This assumption often results in women getting inappropriate behavior from men. This is a reflection of the unequal gender between men and women. The thing most often experienced by women due to this gender inequality is sexual violence. Sexual violence itself is not only in the scope of rape, but it extends beyond that. Sexual violence received by women can occur anywhere, both in public and private spaces, and can cause psychological and physical harm.

Sexual violence experienced by women in Indonesia is not new. The history of sexual violence that occurred in Indonesia is quite long. Since the days of the kingdom, sexual violence against women has occurred frequently. But at that time it was not too much of a concern. Then the most memorable is the sexual violence that occurred in World War II, during the Japanese occupation of Indonesia. In the Japanese era, this process of sexual slavery was systematic, and involved many parties. Starting from the Japanese military rulers to the smallest indigenous rulers, such as kumicho (RT level). The women who are used as jugun ianfu (a term for comfort women from the Japanese side) are not only women from Bumiputera, but from various groups including white women. The method of recruiting used a 
variety of modes, ranging from the most subtle means by which they were promised a better job, to the abusive way of taking force from their families. None of the victims' parents or families dared to fight the Japanese military, because the consequences were murder.[1]

It didn't stop there, even during the New Order era, Indonesian women also experienced sexual violence. The New Order, which was represented by the military, had its own way of sexual exploitation. It started with a single discourse in the public, both through the mass media and the announcement that the Gerwani organization was involved in the scenario of the murder of the generals. Since then, after the events of October 1, 1965, women who were considered to be "enemies of the state" were brutally destroyed through sexual violence during the interrogation process, rape, and sexual slavery in the internment camps, such as what happened at the Teben Plantungan camp in Kendal, Central Java.[1]

Even today, cases of sexual violence in Indonesia are very common. Even Komnas Perempuan said that every two hours there are at least three women in Indonesia who experience sexual violence. According to Komnas Perempuan Commissioner Andy Yentriyani, from 2011 to 2019 his party had received 23,021 cases of sexual violence in the community realm. Part of it is reporting of rape type violence.[2]

Based on this, the authors see that the rampant cases of sexual violence against women to date are due to the lack of a legal protection that can protect women from the threat of sexual violence. The articles in the Criminal Code do not cover all problems in sexual violence. Therefore, a sufficiently complex law is needed to cover the problem of sexual violence that occurs in Indonesia.

\section{Methods}

The type of research used is normative legal research, namely written legal research from various aspects, namely aspects: theory, comparison, structure and composition, scope and material, consistency, general explanation article by article, formality and binding strength of a law, and law language. [3] With a descriptive research.The type of approach used in this research is the regulatory approach and conceptual approach. The legal materials used are primary, secondary and tertiary legal materials. In the framework of legal material procedures, the authors used document study techniques, then described them in accordance with the main problems that were studied qualitatively.

In this study, primary data and secondary data were used. Primary data were collected through observation and interviews. Secondary data is collected through literature / document studies, namely on legal materials that are relevant to the research problem. This research method is carried out in the form of previous studies, textbooks, related news in print media, as well as online data search on the internet. And this method is very useful because it does not interfere with the object of research or the atmosphere of research [4].

This research is descriptive in nature, so the sampling technique used is non-probability sampling, meaning that in this study there is no definite rule on how many samples must be taken in order to represent the population. Data processing and analysis techniques in this study will be carried out qualitatively. All data from the research results were collected both from primary data and secondary data, processed and analyzed by systematically compiling the data. The data that has been compiled are linked between one data and another, then interpreted to understand the meaning of the whole data. The analysis process continues since the search for data in the field and continues until the analysis stage [4] . 


\section{Result and Discussion}

\section{Handling of Sexual Violence in the Criminal Code}

The Criminal Code also regulates sexual violence. The rules regarding sexual violence are found in book II on Crime, in Chapter XIV on Crimes against Decency. The rules regarding sexual violence are regulated in Article 285 to Article 295 of the Criminal Code.[5]

However, the provisions in the Criminal Code on sexual violence are very limited. Broadly speaking, the only forms of sexual violence are rape and sexual immorality. Even the available arrangements have not fully guaranteed the protection of victims' rights, such as the formulation of articles that stipulate that one of the elements is a threat, so that victims who are in a relationship in a condition unable to give the real consent, not covered by these provisions.[6]

In addition, the provisions regarding rape are difficult to apply if the rape is carried out not through the penis (male) to the vagina (female). This happens because, although the crime of rape in the Criminal Code is regulated in Article 285 to Article 288 of the Criminal Code, the word "rape" only exists in Article 285 of the Criminal Code, while other articles use the word "intercourse." The word "intercourse" according to R. Soesilo, refers to the Arrest Hooge Raad February 5, 1912, which is a complaint between male and female genitalia that is carried out to have children.[6]

Meanwhile, Soetandyo Wignjosoebroto defines rape as an attempt to wreak sexual desire by a man against a woman in a manner which according to morals and / or the applicable law violates.[7] So rape is not just about intercourse.

So if there is a case, which does not meet the sexual requirements referred to in the Criminal Code, then that action turns into obscene act. In addition to obscuring the context of the criminal act of rape, the use of the offense for obscene acts of rape is also detrimental to the victim because the threat of punishment is lower than the threat of rape, thus preventing the fulfillment of a sense of justice for the victim.[7]

Therefore, the regulations in the Criminal Code cannot cover all problems of sexual violence experienced by women. This also triggers the rampant sexual violence at this time. So according to the author, there is a need for new regulations that further regulate sexual violence and can become a legal umbrella for women in dealing with problems of sexual violence.

Therefore, it is necessary to clearly see the reasons for the importance of laws that specifically regulate sexual violence as follows: 1 . The rate of sexual violence in Indonesia continues to increase. 2. Cases of sexual violence are detrimental to women, who are often victims. 3. Not creating a deterrent effect for the perpetrator after the incident. 4. Enforcement of cases of sexual violence is often not from the perspective of the victim. 5. Lack of legal instruments that are able to fully resolve every sexual violence that has occurred, this is mainly from the aspect of the availability of regulations. 6 . In order to reduce the number of sexual violence, it is necessary to optimize the function of the commissions that oversee various sectors of sexual violence cases. 7. The enforcement of cases of sexual violence is considered less firm. 8. The importance of maximizing the proper function of rehabilitation and recovery for victims of sexual violence. 9. Access to seek, seek and obtain justice for 
victims is still not wide open. 10 . The justice system for sexual violence, especially against children, is not yet supportive.[8]

\section{Comprehensive Substance in Handling Sexual Violence}

In the legal developments that occur, the emergence of the Bill Draft on the Elimination of Sexual Violence can be an answer to the problems that occur. This is because the Draft Law on the Elimination of Sexual Violence provides more detail on sexual violence.

The Bill Draft on the Elimination of Sexual Violence explains that there are 9 (nine) types of sexual violence. As stated in Article 11 paragraph (1) of this bill, sexual violence consists of: a. sexual harassment; b. sexual exploitation; c. forced contraception; d. forced abortion; e. rape; f. forced marriage; g. forced prostitution; h. sexual slavery; and i. sexual torture. Based on this, the scope of sexual violence will be more complex.[9]

In addition, the Bill Draft on the Elimination of Sexual Violence regulates the roles and duties of State Institutions, Government and Local Governments to carry out prevention of sexual violence. This regulation is not contained in the Criminal Code, and cannot be regulated by the KUHP because this content is not a criminal act. Considering the prevention of sexual violence is an important matter, this prevention must be regulated in laws and regulations outside the Criminal Code, namely the Bill Draft on the Elimination of Sexual Violence. What is meant by Prevention in the Bill Draft on the Elimination of Sexual Violence is all efforts to prevent sexual violence from occurring and sexual violence from recurring. Prevention of sexual violence is one of the scopes of eliminating sexual violence which is the obligation of the state, which in its implementation is carried out by involving families, communities and corporations.[6]

This Bill Draft also regulates the roles and duties of service provider institutions in the protection and recovery of victims, things that are not regulated by the Criminal Code, because the Criminal Code does not regulate provisions other than criminal. This Bill Draft also complements the roles and duties of the Witness and Victim Protection Agency to provide protection for witnesses and victims of sexual violence.[6]

Not only that, the Bill Draft on the Elimination of Sexual Violence can not only fill the legal void but also a commitment for this nation to carry out the 5th point of the Sustainable Development Goals (SDGs), namely regarding gender equality and the protection of women. Regarding the SDGs itself, it has been stated in Presidential Regulation Number 59 of 2017 concerning the Implementation of Achieving the Sustainable Development Goals. Thus, the need for a law that specifically regulates sexual violence is increasingly justified normatively.[10]

In terms of criminal procedural law, the law on the Elimination of Sexual Violence has regulated the obligations and prohibitions for law enforcement officers who handle cases of sexual violence, especially the obligation to ensure that victims receive assistance during the legal process from a companion who has knowledge and expertise on the handling of victims with a human rights and gender perspective. as well as the availability of a payment scheme for material and / or immaterial damages that will be imposed on the perpetrator as an additional form of punishment. This is to ensure that victims have the courage to report the violence that befell themselves without fear, because the data held by Indonesian Lanterns says that $93 \%$ of survivors of sexual violence (verbal, physical non-sexual, to rape) do not report their cases to law enforcement officials. For reasons such as shame, fear of being blamed and not trusted, having no evidence, not being supported by family and friends, to intimidation from the perpetrator.[10] 
Based on the above, the writer believes that the Bill Draft on the Elimination of Sexual Violence can be the answer to the rise of sexual violence in Indonesia. So the authors hope that the government will immediately pass the Bill Draft on the Elimination of Sexual Violence into a Law. It is hoped that later this law can become a legal protection for women to protect victims of sexual violence due to gender inequality.

\section{Conclusion}

Problems faced by women such as sexual violence due to gender inequality are an urgency in the realm of law today. The rise in cases of sexual violence occurs because regulations on sexual violence have not been able to cover all. Such as the Criminal Code which is currently still in effect for dealing with sexual violence. The regulations in the Criminal Code only cover rape and obscene acts, while sexual violence has a much larger scope. Therefore, women are entitled to the right legal protection. The Bill Draft on the Elimination of Sexual Violence contains regulations that can not only cover all spheres of sexual violence but can also fill legal gaps, regulate the prevention of sexual violence, and the protection and recovery of victims. Therefore it is hoped that the Bill Draft on the Elimination of Sexual Violence will soon be passed into a Law. Because this Bill Draft can deal with the problem of sexual violence in Indonesia.

\section{References}

[1] A. Mariana, "Perbudakan Seksual: Perbandingan antara Masa Fasisme Jepang dan Neofasisme ... - Anna Mariana - Google Buku," Marjin Kiri, 2015. .

[2] “Komnas: Tiap 2 Jam, 3 Perempuan Indonesia Alami Kekerasan Seksual.".

[3] B. Ashofa, "Metode Penelitian Hukum," Reneka Cipta, 2001. .

[4] J. Ibrahim, "Teori \& Metodologi Penelitian Hukum Normatif," Teor. Metodol. Penelit. a., 2006.

[5] kementrian hukum dan Ham, "Kitab Hukum Pidana Indonesia," vol. 53, no. 9, pp. 1689-1699, 2013.

[6] Komnas Perempuan, "RUU Penghapusan Kekerasan Seksual Sebagai UU yang Mengatur Tindak Pidana Khusus," Kekhususan Ranc. Undang. Penghapusan Kekerasan Seksual, pp. 1-8, 2017.

[7] S. Marzuki, E. Prasetyo, A. M.-F. H. U. I. Indonesia, and U. 1997, "Pelecehan Seksual," 1997.

[8] A. Rahmi, "Urgensi Perlindungan Bagi Korbankekerasan Seksual Dalam Sistem Peradilan Pidana Terpadu Berkeadilan Gender," J. Mercat., vol. 11, no. 1, p. 37, 2018, doi: 10.31289/mercatoria.v11i1.1499.

[9] "Draft per 12 Oktober 2016 Rancangan Undang-Undang No. ... Tahun.... Tentang Penghapusan Kekerasan Seksual.” Pp. 1-57, 2016.

[10] Dewan Mahasiswa Justicia Mahasiswa Ugm, "Rilis Kajian: Miskonsepsi Ruu Pks Dan Penundaan Pembahasan Oleh Dpr," 2020, Pp. 0-17. 